\title{
Guggenheim Fellowships Awarded
}

The John Simon Guggenheim Memorial Foundation awarded a 2015 fellowship to Wendy K. Tam Cho, a professor of politi-

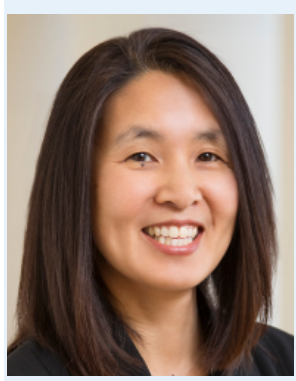

cal science and of statistics at Unversity of Illinois (UI). Cho uses statistical and computational models to look for ways to advance social science. She is a senior research scientist at the National Center for Supercomputing Applications.

She is affiliated with the Illinois Informatics Institute, the Cline Center for Democracy, the CyberGIS Center for Advanced Digital and Spatial Studies, and the Computational Science and Engineering Program at UI.

"My primary research agenda focuses on building statistical and computational models for social science," she said. "In recent years, this has been driven by a desire to discover creative and important ways for social scientific progress and societal advances to march alongside scientific and technological growth."

Her parents immigrated to the United States shortly before she was born and wanted her to have the college education they lacked. She loved both math and politics and studied both, interested in the concept of power and how some people achieve and legitimize power in human societies. Quantitative social science was hardly a field when she entered graduate school, she said.

She also founded and teaches in a local math circle that is open to all children (from kindergarten through high school) in the Champaign-Urbana community. She said it meets weekly to explore the beauty of mathematics, covering topics not encountered in standard school curriculums-fourdimensional shapes, non-Euclidean geometry, number theory concepts, and applications of graph theory, to name a few.

She will use her fellowship on work aimed at harnessing the power of information by developing statistical and mathematical models to guide computing technology toward intelligent information extraction, a UI news release said.
Cho earned her doctorate in 1997 from the University of California, Berkeley and joined the UI faculty that same year.

Mark Fathi Massoud, politics department and legal studies program, University of California, Santa Cruz, has been awarded a Guggenheim Fellowship.

Massoud's research focuses on the institutionalization of law and human rights in conflict settings and authoritarian states, and on Islamic law and society. He holds JD and PhD degrees from UC Berkeley.

His recent book, Law's Fragile State: Colonial, Authoritarian, and Humanitarian Legacies in Sudan (Cambridge University Press) received the Honorable Mention Award for the APSA C. Herman Pritchett Prize, for best book in law and courts, and the Law and Society Association Herbert Jacob Book Prize.

The book explores how colonial administrators, post-colonial state leaders, and humanitarian aid groups use law to establish social, moral, political, and economic order. But the process toward legitimacy, as Massoud shows, is often achieved through illegitimate means.

For Sudan, the transition from colonialism resulted in fluctuating forms of democracy, autocracy, military rule, warfare, and violence.

"The case of Sudan reveals law's multifaceted nature and ultimately, how law is essential to, rather than missing from, unstable political environments," Massoud shares.

Massoud points out that disrupting authority may take chaotic and bloody directions. "Where the law supplants violence," he said, "it can allow an illegitimate government to appear more moderate, thereby augmenting its authority."

As Massoud argues, the problem is not so much the law itself, but how political actors can manipulate and manufacture law for their own advantage, including colonial administrators, state authorities struggling to main- tain power, and aid groups working to build the rule of law after a civil war. The case of Sudan demonstrates how "the moral qualities associated with law's power, in authoritarian regimes as in democratic countries, reflect the goals of the actor who creates or uses the law."

Northwestern University Weinberg College of Arts and Sciences faculty member Monica Prasad is among the newly named 2015 Guggenheim Fellows.

Prasad, professor of sociology and faculty fellow at the Institute for Policy Research at Northwestern, studies comparative-historical sociology, economic sociology, and political sociology. With her Guggenheim fellowship, Prasad is writing a book on the Reagan tax

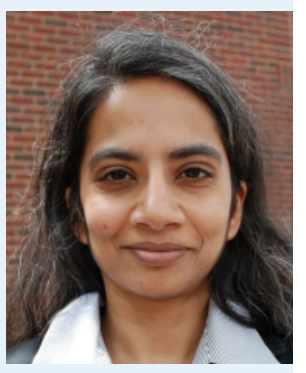
cut of 1981, based on access to previously unseen documents from the Reagan presidential library.

"The idea is that the US has fallen into this low-tax regime where politics is always about cutting taxes, and the Reagan tax cut was really the start of that," Prasad said.

Prasad's most recent book, The Land of Too Much:American Abundance and the Paradox of Poverty (Harvard University Press, 2012), received several awards, including the American Sociological Association's award for the best book in sociology. The book develops a demand-side theory of comparative political economy to explain the surprisingly large role of the state in the United States, its origins in the nineteenthcentury revolution in agricultural productivity, and its consequences for undermining a European-style welfare state and leaving US economic growth dependent on "mortgage Keynesianism."

Her first book The Politics of Free Markets (University of Chicago Press, 2006) also received a book award, and she counts a Fulbright and a National Science Foundation Career Award among her other honors. 